PF 2019 (LXXIII): 207-219

\author{
IZABELLA ŁAWECKA \\ Instytut Polonistyki Stosowanej \\ Uniwersytet Warszawski \\ ul. Krakowskie Przedmieście 26/28, 00-927 Warszawa \\ tel. (+48) 225520374 \\ e-mail: izabella@lawecka.pl
}

\title{
O SKŁADANIU ŻYCZEŃ. GLOSA DO OPISU CZASOWNIKA ŻYCZYĆ I NAZYWANEGO PRZEZ NIEGO AKTU MOWY
}

SŁOWA KLUCZOWE: akty mowy, semantyka, składnia, językowe zachowania grzecznościowe

KEYWORDS: speech acts, semantics, syntax, linguistic politeness behaviour

\section{CHARACTERISTICS OF THE VERB ŻYCZYĆ ('TO WISH') AND THE SPEECH ACT DENOTED BY THE VERB}

\begin{abstract}
The paper presents semantic and syntactic description of the verb życzyć ('to wish') and the speech act denoted by this verb. The study also focuses on the context of utterances and the intentionality of expressing one's wishes. By analyzing the syntactic positions of the verb and the aims of the speaker, the author attempts at characteristizing wishes as linguistic politeness behaviour.
\end{abstract}

Czasownik $\dot{z} y c z y c ́$ wchodzi w skład co najmniej dwu jednostek języka: ktoś $\dot{z} y c z y$ komuś czegoś i ktoś życzy sobie. Obie są odnotowane w słownikach bądź w odrębnych formach hasłowych ${ }^{1}$, bądź jako dwa różne znaczenia jednego hasła².

1 Życzyć sobie jako odrębną formę hasłową notują m.in. Słownik 100 tysięcy potrzebnych słów pod red. J. Bralczyka (2005) czy Wielki słownik poprawnej polszczyzny PWN pod red. A. Markowskiego (2004).

2 Życzyć sobie najczęściej jest podawane jako jedna z definicji hasła życzyć, zwykle drugorzędna. Poświadczają to np. Słownik warszawski, SJPD, ISJP czy słowniki etymologiczne W. Borysia (2005) i A. Brücknera (1927). 
W niniejszym artykule analizie poddam czasownik $\dot{z} y c z y c ́$ jako $\dot{z} y c z y c ́$ komuś. Celem mojego studium jest, oprócz ustalenia właściwości czasownika, również omówienie życzeń jako aktu mowy³.

Już sama próba refleksji semantycznej wymaga uwzględnienia czasu: życzymy tego, co może się dopiero wydarzyć ${ }^{4}$, a więc przedmiotem życzenia są zdarzenia umieszczone w przyszłości względem czynności wypowiadania. Dotyczą zatem celu do osiągnięcia przez odbiorcę (Greń 1994, s. 234). Życzyć może wiązać się z przeszłością, ale wówczas wskazuje się na to, aby to, co przeszłe, już nie zachodziło (por. Życzył mu, aby więcej nie chorował) ${ }^{5}$, a także teraźniejszością - gdy wskazuje się na to, aby to, co trwa obecnie i jest korzystne, pozostało niezmienione (por. Życzyła mu, żeby zawsze był taki szczęśliwy).

Życzenia, podobnie jak inne akty mowy, są działaniem mownym i odczytujemy je z kontekstu. W pierwszej osobie liczby pojedynczej i mnogiej nie jest zatem konieczne użycie czasownika określającego tenże akt mowy. Czasownik $\dot{z} y c z y c ́$ albo jego bliskoznaczniki pojawiają się, kiedy akt mowy jest referowany (w wypowiedziach zdających sprawę z aktu składania życzeń), oprócz tych są też wypowiedzi performatywne ${ }^{6}$, sprawcze, podczas wygłaszania których akt życzeń realizuje się jako czynność mowna. Przykłady omawiane w tej pracy posiłkują się obu tymi typami, tak aby pokazać możliwie jak najwięcej relacji i właściwości czasownika.

Warto nadmienić, że o ile nieperformatywne $\dot{z} y c z y c ́$, które występuje w mowie zależnej, jest wiązane z użyciem czasownika, o tyle akt performatywny pozwala zastosować jego elipsę. Co więcej, z powodu dążenia do ekonomizacji wypowiedzi częściej wypowiadamy samą treść życzenia niż cały ciąg z nazwaniem czynności mowy, której właśnie dokonujemy. W tym samym celu stosowane są też rozkaźniki.

(1) Życzę Ci udanych zakupów.

(2) Szczęśliwej podróży!

(3) Leć szczęśliwie!

W przykładzie (1) agens dodatkowo zdaje sprawę z tego, jaką czynność mowy wykonuje. Gdyby zdanie skrócić do formy Udanych zakupów, treść życzeń i jej

\footnotetext{
Przyjmuję definicję aktu mowy za J. Austinem (1993).

4 Ta różnica znaczeń została już odnotowana w Słowniku synonimów polskich z 1885 (Krasiński 1885, s. 247).

5 Choć zdanie nie jest jednoznaczne, może wiązać się z przeszłością, jeśli przyjmiemy, że jest wypowiadane, gdy ktoś już wyzdrowiał. Jeżeli założymy, że wypowiadane jest do osoby, która właśnie jest chora - wówczas odnosi się do teraźniejszości.

6 Wypowiedziom performatywnym w ujęciu filozofii języka i pragmatyki poświęcona jest monografia E. Grodzińskiego (1980).
} 
odbiór nie ulegają zmianie. Użycie krótszej formy wydaje się właściwsze i brzmi naturalniej w codziennej komunikacji.

(4) Życz mi powodzenia!

Zdania rozkazujące poświadczają wartość życzeń w kulturze społecznej ${ }^{7}$ oraz ich funkcję w budowaniu relacji. Tego typu wypowiedzi (por. (4)) są projektowaniem określonych zachowań mownych. W powyższym przykładzie osobą, której ma się życzyć, jest sam nadawca wypowiedzi. Ze zdania wynika, że oprócz oczekiwania, aby nadawcy powiodło się w konkretnej sytuacji, sam fakt życzenia ma niebagatelne znaczenie. Życzeniom przypisywana jest szczera intencja ${ }^{8}$, o której Kazimierz Sikora pisał tak:

W świetle faktów językowych najważniejsze jest, że nadawca chce, aby odbiorca doświadczył jakiegoś dobra (Sikora 2013, s. 181).

Warunek intencji znajduje się także w eksplikacji Anny Wierzbickiej:

Życzę ci Z. = Chcąc, żebyś miał Z., Wiedząc, że nie mogę tego spowodować, mówiąc to, Mówię: chcę dla ciebie Z. (Wierzbicka 1973, s. 217).

Życzenia powinny być zatem wypowiedziane i chciane przez osobę, która je składa (choć, jak wykaże dalsza analiza, bywają od tego odstępstwa). Stąd może wynikać, że w tego typu komunikatach perlokucja nie odnosi się do przyjęcia pewnego zachowania społecznego, ale również po prostu do odebrania aktu, jakim są życzenia9 . To podkreśla także istotną funkcję życzeń w społeczeństwie, abstrahując od ich podłoża historycznego i niekiedy z nimi związanego myślenia magicznego.

Osobną kategorię stanowią życzenia wyrażane bez wykładnika życzyć, których treści skonwencjonalizowały się i dziś są uznawane za gotowe konstrukcje składniowe czy szablony językowe, np. dobranoc (które jest ściągnięciem do jednego wyrazu zwrotu życzę ci dobrej nocy), miłego dnia, powodzenia i wiele innych ${ }^{10}$. Życzymy w ten sposób nie tylko przy użyciu podobnych gotowych formuł.

$7 \quad$ Wyrażają szczególne znaczenie czynności życzenia, niejako przywiązanie do samego aktu życzenia.

8 Badacze przyjmują w tej kwestii różne stanowiska. Jeśli przyjąć, że życzenia są zachowaniem grzecznościowym, wątpliwości w ogóle budzi rozpatrywanie ich intencjonalności. „Zachowania grzecznościowe nie podlegają bowiem weryfikacji ani prawdziwościowej, ani nie powinny podlegać weryfikacji ze względu na szczerość mówiącego" (Marcjanik 2008, s. 15).

9 Sytuacja zmienia się, jeśli przyjmiemy, że życzenia mogą być nieszczere i wypowiadane jedynie ze względu na okoliczności, które wymuszają, aby nadawca je złożył. Jeśli wówczas odbiorca życzeń jest świadom nieszczerej intencji (np. ze względu na swoją złą relację ze składającym życzenia), nie przyjmuje aktu życzeń zgodnie z przypisywanymi mu właściwościami życzliwości i szczerości, mimo że akt mowy zaistniał. Do zagadnienia wracam w dalszych rozważaniach.

10 Intencjonalność tego typu gotowych formuł podam w wątpliwość w dalszej części tekstu. 
Nie jest żadnym wykroczeniem językowym, jeśli przy okazji czyichś urodzin albo świąt powiemy: Zdrowia, szczęścia i miłości albo Zdrowia, zdrowia $i$ jeszcze raz $z d r o w i a^{11}$. Ostatni przykład natomiast może obrazować system wartości, w którym zdrowie jest postrzegane jako najcenniejsze.

Zdaje się jednak, że tego typu zachowania społeczne są dopuszczalne przy spełnieniu odpowiednich warunków fortunności. Jednym z nich jest konieczność istnienia jakiejś przyczyny składania życzeń, która będzie znana przynajmniej jednemu ${ }^{12}$ uczestnikowi komunikatu. Trudno wyobrazić sobie sytuację, w której życzenia złożymy bez okazji przypadkowo napotkanej i obcej osobie.

Przekazujemy zatem intencję życzenia na dwa sposoby. Może się wydawać, że w obu przypadkach sednem życzeń jest to, co wyrażają, nie zaś sam fakt życzenia ${ }^{13}$. Niezależnie od tego, czy dookreślimy czynność mowy, którą właśnie wykonujemy, czy wypowiemy samą treść życzeń - celem komunikatu jest wyrażenie aktu mentalnego (intencji). Życzenia powinny być zgodne z wolą nadawcy, choć można polemizować, jeśli chodzi o intencjonalność takich działań mownych, które wynikają $\mathrm{z}$ reguł zachowania się $\mathrm{w}$ towarzystwie, np. przy okazji wesela, kiedy życzenia stanowią spójny element uroczystości, a goście, przychodząc na przyjęcie i dając tym samym znak dobrowolnego wyboru, są niejako zobligowani do ich złożenia.

Czy można natomiast składać życzenia, jeśli wcale nie chce się tego uczynić? Wyrażenia języka zdają się potwierdzać taką możliwość, por.:

(5) Życzyła im szczęścia, mimo że nie chciała, aby byli szczęśliwi.

Zdanie jest przykładem referowania aktu mowy, wyraźnie wyodrębnia akt mentalny (nie chciała) i czynność werbalną, które nie zawsze idą w parze. Zdanie może być akceptowalne jedynie pod warunkiem, że czasownik życzyć oznacza wypowiedzenie ciągu słów sprzecznych z intencją nadawcy składającego

11 Jednak tego typu przykłady budzą wątpliwości, jeżeli chodzi o performatywność wypowiedzi - zostaje bowiem w nich zmieniona formuła warunkująca skuteczność aktu performatywnego.

12 Mowa np. o okoliczności, gdy przyczyna nie jest znana obu stronom od razu. Warto wyobrazić sobie sytuację, w której odbiorca zapomina o swoim święcie i zostaje uświadomiony dopiero w momencie, gdy ktoś składa mu życzenia. Do zaistnienia komunikatu o funkcji życzeń wymagane są przynajmniej dwie jednostki: nadawca i odbiorca. Są to podmioty umowne, o czym mowa w dalszej części artykułu przy okazji odbiorcy opisanemu jako nikt.

13 Z tym powszechnym rozumieniem polemizuje K. Ożóg (1990, s. 7-11). Autor wspomina o pewnych rytuałach językowych obowiązujących wszystkich członków społeczeństwa oraz o działaniach mownych, których wymaga konwencja grzecznościowa, a które nie wynikają wcale z siły illokucji. Odwołując się do zapowiedzianej wcześniej wątpliwości dotyczącej użycia gotowych formuł, warto zastanowić się, czy np. dzień dobry mówimy, aby życzyć komuś dobrego dnia, czy dlatego, że tego wymaga nasza kultura we wskazanej sytuacji komunikacyjnej. 
życzenia ${ }^{14}$. Życzyła zatem, bo wypadało, samo $\dot{z} y c z y c ́$ w tym wypadku jest ściśle ograniczone do życzenia werbalnego.

Mimo że zawsze istnieje odbiorca życzeń, ktoś, w stosunku do kogo mamy intencję życzenia, jednak nie musi być poinformowany o czyimś akcie mentalnym wobec niego, co ilustruje zdanie (8).

(6) Złożył mu najlepsze życzenia.

(7) Życzył mu wszystkiego dobrego.

(8) Życzył mu w duchu szczęścia.

Nie mamy wątpliwości, że w przykładzie (6) akt życzenia zaistniał, życzenia zostały wypowiedziane, a odbiorca dowiedział się o nich. Nieco bardziej kłopotliwy jest przykład (7). Nie ma bowiem pewności, czy życzenia zostały wyrażone explicite, wypowiedziane, czy - tak jak w przykładzie (8) - jedynie pomyślane.

Nie można wyobrazić sobie życzeń bez nadawcy. Co więcej, treści życzeń niejednokrotnie włączają niejako samego nadawcę do życzeń po stronie adresata.

(9) Niech ten Nowy Rok będzie dla nas wszystkich pełen sukcesów.

(10) Żebyśmy zawsze umieli być dla siebie wsparciem.

Może się to odbywać za pomocą form zaimkowych, np. nas czy ruchomej końcówki pierwszej osoby l. mn. -śmy dodawanej do leksemów czasownikowych, a także za pomocą form złożonych, zawierających rzeczownik $\dot{z} y c z e n i a^{15}$.

(11) Życzę nam wszystkim zapału do pracy.

(12) Chciałbym złożyć nam wszystkim najlepsze życzenia.

(13) Składam nam wszystkim serdeczne życzenia.

Przykłady (12) i (13) sugerują świadomość operowania danym aktem mowy w chwili mówienia, referowanie danego zachowania społecznego przez samego mówiącego.

Nie da się zbudować podobnego zdania zdającego sprawę z zaistnienia aktu mowy. W tego typu kontekstach wszyscy uczestnicy aktu stają się równorzędnymi nadawcami. Próba zrelacjonowania działania przyjmie postać: Złożyliśmy sobie najlepsze $\dot{z} y c z e n i a$, a to oznacza istnienie wielu nadawców, co nie do końca jest zgodne z powyższymi przykładami. Złożono nam wszystkim najlepsze życzenia sugeruje obecność dwóch osobnych podmiotów: nadawcy, który jedynie złożył życzenia innym, oraz odrębnego odbiorcy zbiorowego (do którego grona należy również podmiot referujący w zdaniu).

14 Wówczas to kolejny dowód na brak konieczności istnienia szczerej intencji nadawcy.

15 Z. Greń mówi o formach analitycznych, czyli ekwiwalentach czasownika życzyć (Greń 1994, s. 235). 
Czasownik życzyć ma wiele ekwiwalentów: życzenia można składać, przesyłać, przekazywać etc. Ekwiwalenty te posiłkują się nominalną formą życzenia pochodzącą od czasownika życzyć. Można je potraktować jako wyrazy bliskoznaczne od $\dot{z} y c z y c ́$, natomiast, z racji ich dwudzielnej budowy, funkcjonują inaczej ${ }^{16}$.

Co ciekawe, formy złożone uniemożliwiają wyrażanie oceny negatywnej ${ }^{17}$. Dlatego zdanie

(14) Życzył mu tego, co najgorsze.

jest akceptowalne. Niedopuszczalne zaś jest stwierdzenie

(15) ^Złożył mu życzenia wszystkiego najgorszego.

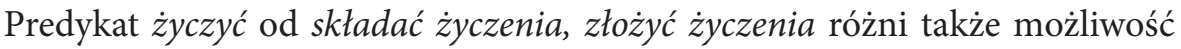
budowania odpowiednich konstrukcji z wyrażeniami przyczyny aktu mowy (czyli okazji, z powodu której życzymy) oraz treści życzeń. Otóż formy złożone dopuszczają konstrukcje z elipsą przedmiotu życzenia (Greń 1994, s. 235). Dlatego akceptowalne jest zdanie:

(16) Złożył mu życzenia z okazji urodzin.

Jest miejsce na treść życzeń, które bywa nierealizowane w zależności od sytuacji.

(17) Złożył mu życzenia wszystkiego najlepszego z okazji urodzin.

Tego typu operację uniemożliwia predykat $\dot{z} y c z y c ́$, dlatego poniższe zdanie jest nieakceptowalne.

(18) ${ }^{*}$ Życzył mu z okazji urodzin.

Zupełnie odwrotnie wygląda łączliwość obu form czasownikowych ( $\dot{z} y c z y c ́$ i jego złożonych wariantów), jeżeli chodzi o argument wyrażający przedmiot życzeń. O ile dla predykatu $\dot{z} y c z y c ́$ wyrażenie przedmiotu jest wystarczające, o tyle zbyt niezgrabnie brzmią ich złożone odpowiedniki w podobnym kształcie.

(19) Życzył mu szczęśliwego lotu.

(20) Złożył mu życzenia udanych zakupów.

Forma złożona podana w przykładzie (20) wykazuje tendencję do frazeologizacji, por. składać najserdeczniejsze życzenia, życzenia urodzinowe etc. Konstrukcja złożyć ̇̇yczenia czego brzmi w tym miejscu nienaturalnie.

Na gruncie pragmatycznym należy założyć, że przedmiot życzeń dotyczy wartości ogólnie przyjętych jako pozytywne albo takich, o których wiemy, że są dobre

16 Różnią się łączliwością składniową.

17 To dowód na to, że życzyć objęło też złorzeczyć, a życzenia są nadal wyraźnie odróżnialne od złorzeczeń. 
dla odbiorcy ${ }^{18}$. Życzenia powinny wreszcie dotykać kwestii zgodnych z wiedzą adresata i stopniem zażyłości z odbiorcą. Życzenia nietaktowne lub osobiste mogą być źródłem nieporozumień, a w efekcie mogą przynieść negatywny skutek i sprawić przykrość odbiorcy. Dobór pozytywnych treści ukierunkowuje zasada Nie $\dot{z} y c z$ drugiemu, co tobie niemiłe. Życzliwość życzeń podkreślają również definicje słownikowe ${ }^{19}$. Owszem, można źle życzyć, jednak w tym znaczeniu wchodzimy w obręb złorzeczeń, te zaś wykraczają poza obręb rozważań. Sformułowania $\dot{z} y c z y c ́$ źle można za pomocą negacji użyć w wypowiedziach nacechowanych pozytywnie.

(21) Nikomu źle nie życzy.

W niektórych sformułowaniach sam czasownik życzyć nie wyraża pozytywnego wartościowania.

(22) ^Jeżeli mi życzysz, pozwól mi jeszcze raz zmierzyć się z tym.

Zdanie (22) nie będzie miało sensu, dopóki nie użyjemy formy dobrze $\dot{z} y c z y s z$.

(23) Niech Bóg wynagrodzi tym, którzy nam dobrze życzą.

Podobną funkcję pełni negacja od życzyć. Sformułowanie nie życzyć komuś czegoś w tym kontekście niesie dobre intencje nadawcy w odniesieniu do negatywnego opisu sytuacji.

(24) Nikomu nie życzy spotkać się z nim w podobnych okolicznościach.

Predykat $\dot{z} y c z y c ́$ zatem otwiera pozycję składniową CZEGOŚ. Konieczność użycia argumentu wyrażającego okazję czy przyczynę życzeń jest dyskusyjna (ale przemawia za nią to, że życzenia są z okazji, np. życzenia bożonarodzeniowe - prawdopodobnie to pozycja po czasowniku $\dot{z} y c z y c ́$ ), istotniejsze zdaje się użycie argumentu odnoszącego się do przedmiotu życzeń.

(25) Życzyła mu samych radosnych chwil z okazji nadchodzących Świąt.

Owa przyczyna, okazja do życzeń może być wyrażana na wiele sposobów. Jedną z nich jest skonwencjonalizowana formuła $z$ okazji, inną - $w d n i u$.

(26) Życzył żonie zdrowia z okazji jej urodzin.

(27) Życzył żonie zdrowia w dniu jej urodzin.

Zdaje się, że $z$ okazji jest jedynie przyczynkiem do wypowiedzenia życzeń, których spełnienia nadawca zawsze pragnie dla odbiorcy (życzę przy okazji czegoś, a więc dominantą jest czynność życzenia). $W$ dniu (jako dokładne określenie

18 Przy czym istnieje wyraźna różnica między życzyć (można dobrze i źle) a składać życzenia (tylko dobre).

19 Chodzi o definicje $\dot{z} y c z y c ́$, np. jako dobrze życzyć, być życzliwym (SW) albo radzić życzliwie (SJPD). 
temporalne) podkreśla aktualność działania mownego, oznaczonego w czasie. $\mathrm{Z}$ tego powodu możemy odnieść wrażenie, jakoby życzenia składane $w$ dniu były umotywowane właśnie tą okolicznością i ten fakt zostaje zaakcentowany w wypowiedzi.

Rzeczywiście konieczność otwierania pozycji przeznaczonej na wyrażenie okazji jest dyskusyjna, nie musimy w naszym komunikacie tłumaczyć się z powodu składania życzeń, ale to dlatego, że taka przyczyna istnieje, i przy założeniu, że jest ona znana obu podmiotom wypowiedzi. Zakładam, że zawsze istnieje jakaś przyczyna, sytuacja motywująca określone zachowanie społeczne. Często taką przyczyną jest chęć nadawcy, aby sprawić komuś przyjemność lub jego własne doświadczenia czy spostrzeżenia (por. Nikomu nie życzę tego).

Motywacja taka może być bardzo różnoraka, biorąc pod uwagę, jak różne są życzenia, np. świąteczne (z okazji świąt powszechnych), okazjonalne (motywowane zaistniałą okolicznością, np. awansem) czy sytuacyjne (które motywuje dana sytuacja społeczna, np. szczęśliwej podróży). Może zatem wynikać z powo$\mathrm{du}$, a nie z konkretnej okazji. Istnienie przyczyny życzenia nie oznacza jednak konieczności jej wyrażania w akcie mowy, jeśli jest znana obu stronom lub zostanie prawidłowo odczytana przez odbiorcę.

Według WSJP pod redakcją Piotra Żmigrodzkiego pozycja przeznaczona dla nadawcy życzeń jest realizowana przez rzeczownik osobowy - życzyć może nie tylko osoba czy jednostka społeczna (np. rodzina Kowalskich, Kowalscy z dziećmi etc.), lecz także każda inna zbiorowość ludzka, np. redakcja, firma czy sieć sklepów.

W kontekście uwag o nadawcy zasadne jest odróżnienie wypowiedzi sprawczych od aktów nieperformatywnych, a także formy ustnej od pisemnej. W przekazie ustnym na ogół niewypełniana jest pozycja przeznaczona dla agensa, a coraz powszechniejsze są formuły typu Wszystkiego najlepszego!. Odstępstwem od podobnego konstruowania wypowiedzi jest chęć poinformowania o nadawcy zbiorowym, kiedy to posługujemy się zwrotem $w$ imieniu.

Podobną wartość przypisujemy argumentowi KOMU - adresatem i zarazem odbiorcą życzeń może być osoba lub grupa osób, zbiorowość, firma, instytucja, grupa społeczna lub zawodowa. Dowodów dostarczają nam chociażby święta tematyczne takie jak Dzień Kobiet, Dzień Nauczyciela etc. Zdaje się, że odbiorca życzeń jest niezbędny, aby mógł zaistnieć akt życzenia.

Życzenia zwykle wypowiadamy, choć możemy życzyć w duchu ${ }^{20}$. W związku z tym nic nie stoi na przeszkodzie, aby życzyć hipotetycznie i nikomu, co w tym kontekście oznacza bycie życzliwym. Przykład (28) jest porównywalny ze zdaniem Wszystkim życzył dobrze oznaczającym cechę życzliwości.

20 To sytuacja, w której jest adresat, ale nie ma odbiorcy. 
(28) Nikomu nie życzył źle.

(29) Życzył samych pięknych chwil.

(30) ${ }^{2}$ Życzył komukolwiek wszystkiego dobrego.

Uzasadnieniem braku odbiorcy w tym wypadku jest akt mentalny, który skupia się na odczuciach agensa i je opisuje. Mimo że odbiorcą jest nikt, pozycja składniowa w zdaniu przewidziana na niego jest uzupełniona. Nie można stworzyć takiego zdania, w którym nie będzie żadnego odbiorcy życzeń - pod warunkiem że nie jest to kolejne zdanie $\mathrm{z}$ zastosowaną elipsą po zdaniu, w którym odbiorca został określony. Co więcej, prawidłowe są wypowiedzi, w których życzymy nikomu lub wszystkim, a dewiacyjne te, w których odbiorca jest kimkolwiek ${ }^{21}$.

Sam czasownik natomiast otwiera miejsce dla przedmiotu życzeń na dwa sposoby: w formie zdaniowej ( $\dot{z} y c z y c ́$, żeby) albo wtórnej - rzeczownikowej ( $\dot{z} y$ czyć czego). Całą wypowiedź zamykają zatem pozycje przeznaczone dla nadawcy i odbiorcy, pozycja markowana przez zaimek czegoś oraz wskazująca na istnienie okazji lub przyczyny (KTOŚ ŻYCZY KOMUŚ CZEGOŚ Z JAKIEJŚ OKAZJI/ PRZYCZYNY). Należy jednak wspomnieć również o dodatkowym, lecz częstym w użyciu elemencie opisu - określeniu tego, w jaki sposób życzymy ${ }^{22}$. Tego typu dookreślenia pełnią funkcję wzmacniającą przekaz i przekonującą o szczerości wypowiedzi lub stopniu życzliwości.

Kazimierz Ożóg zalicza życzenia do tzw. okazjonalnych zwrotów grzecznościowych. Jedną z ich cech jest „tendencja do intensyfikacji niektórych formul” (Ożóg 1990, s. 58). To właściwość zarówno wypowiedzi performatywnych, jak i nieperformatywnych.

(31) Wszystkim z całego serca życzę sukcesów.

(32) Z głębi serca życzył mu powrotu do zdrowia.

(33) Na pewno życzyła nam dobrze.

W podobny sposób czasownik życzyć łączy się składniowo z przysłówkami. Można zatem życzyć dobrze lub źle, szczerze, gorąco.

Być może motywacją do życzeń, których prawdziwość nadawca podkreśla dodatkowymi określeniami, jest to, że czasownik życzyć jest niefaktywny ${ }^{23}$, może być użyty ironicznie, nieprawdziwie lub wymagać prawidłowego odczytania z kontekstu.

${ }_{21}$ Po pierwsze, wynika to z użycia zaimka nieokreślonego komukolwiek, który wskazuje na brak konkretnego odbiorcy. Po drugie, co za tym idzie, wynika to również z własności życzeń i założenia, że musi istnieć odbiorca.

22 Pozycja ta nie wynika ze znaczenia analizowanego czasownika.

23 Czasowniki faktywne wymagają prawdziwości sądów w zdaniu podrzędnym. Ze wcześniejszej analizy wynikło, że $\dot{z} y c z y c ́$ nie zawsze zakłada prawdziwość intencji nadawcy. 
(34) Paweł życzył jej wygranej, choć wszyscy wiedzą, że zależało mu na nagrodzie głównej.

(35) Paweł życzył jej wygranej i wszyscy wiemy, że rzeczywiście tak jest.

(36) Paweł życzył jej wygranej, ale nikt $\mathrm{z}$ nas nie jest pewien jego intencji ${ }^{24}$.

Kierować do innych życzenia możemy nie tylko przy użyciu czasownika $\dot{z} y$ czyć i form składać życzenia, złożyć życzenia. Kazimierz Sikora wymienia inne jednostki leksykalne służące temu celowi, takie jak: niech, żeby, oby, bodaj, byle (Sikora 2013: 185-186). Przy czym każde z nich niesie odrębną wartość semantyczną (autor wspomina o szczególnym znaczeniu oby, zakładającym obawę mówiącego przed negatywnym stanem rzeczy, należącą do presupozycji. Tej funkcji nie pełnią pozostałe wyżej wspomniane operatory). Dlatego w zdaniu

(37) Oby ci się powiodło w nowej pracy.

wnioskujemy, że mówiący ma obawy, czy aby na pewno tak się stanie. Taką sugestię wprowadza kontekst wypowiedzi, a nie struktura. Rzeczywiście zdanie (37) wypowiadane $\mathrm{z}$ troską pozwala wyciągnąć taki wniosek, zupełnie inaczej jest w zdaniach wypowiadanych z przekąsem, skłaniającym się bardziej ku magicznym złorzeczeniom, nie zaś życzeniom (por. Oby cię pokręciło).

Za pomocą wspomnianych partykuł możemy składać wyszukane życzenia $\mathrm{w}$ formie rozbudowanej narracji.

(38) Niech magiczna noc wigilijnego wieczoru przyniesie nadzieję wszystkim, którzy zwątpili.

Oprócz skonwencjonalizowanych formuł życzymy także, używając trybu rozkazującego ${ }^{25}$.

(39) Bądź szczęśliwa!

(40) Boże, dopomóż!

Pełna dowolność wyboru formy życzeń dotyczy również szyku składanych życzeń. Jednak w zależności od konkretnego schematu zdania wymusza ono szereg konkretnych jednostek leksykalnych w odpowiedniej formie fleksyjnej. I tak wyrażenie $\dot{z} y c z y c ́$ czegoś pociąga za sobą konieczność użycia formy nominalnej, najczęściej w postaci wyliczeń (np. zdrowia, szczęścia i sukcesów w pracy; w odróżnieniu od formy zdaniowej wprowadzanej przez spójnik żeby). Podobnie formy rzeczownikowej wymagają życzenia wprowadzone od zwrotu $z$ okazji czy w dniu.

Bardzo częstą (szczególnie w przekazie pisemnym) praktyką jest rozpoczynanie od treści życzeń i kończenie podpisem. Jest to uzasadnione zachowywaniem

\footnotetext{
24 Zdanie potwierdza wątpliwości, jeżeli chodzi o szczerą intencję nadawcy.

25 Adresatem podobnych rozkaźników jest zwykle sam odbiorca życzeń lub osoby mające moc sprawczą, istoty boskie, związane z wiarą.
} 
tradycyjnej postaci listów czy pocztówek, w których podpis umieszczamy właśnie na końcu wypowiedzi. A skoro zamierzamy pozostawić swoją sygnaturę, w naturalny sposób życzenia formułujemy bezosobowo.

(41) Świąt pełnych miłości życzą Kowalscy.

(42) Pogody ducha i wielu wspaniałych chwil przesyła rodzina Kowalskich.

Zdaje się, że tego typu forma komunikatu tworzy dystans. Aby się go pozbyć, użytkownicy języka wykorzystują zwroty do adresata podkreślające indywidualny stosunek piszącego do odbiorcy (por. Kochanej cioci, Najlepszej mamie pod słońcem).

Takie sformułowania rzadko pojawiają się w przekazie ustnym (zachowały się w języku w użyciu grzecznościowej formy trzecioosobowej, np. podczas zwracania się do rodziców). Zarówno w przekazie ustnym, jak i pisanym charakterystyczne jest użycie formuł równoważnikowych.

(43) Najlepsze życzenia na nowej drodze życia.

Na zakończenie warto odwołać się do jeszcze jednej własności życzeń. Przenikają się i mogą zawierać w sobie inne akty mowy. Przede wszystkim oscylują między wyrażaniem życzeń a komplementowaniem.

(44) Bądź zawsze taka promienna jak dziś.

(45) Żeby ten piękny uśmiech nigdy nie schodził z twojej twarzy.

Zdarza się również, że pod pretekstem życzeń nadawca przechwala się.

(46) Żebyś awansował tak szybko jak ja!

(47) Niech Ci się poszczęści w miłości tak jak mi.

(48) Wygraj te zawody, bo jeszcze nikt w naszej rodzinie nie zrobił tego po mnie.

Życzenia mogą również być przyczyną nieporozumień. Zdarzają się niejasno skonstruowane komunikaty, w których intencjonalność nadawcy jest kłopotliwa do ustalenia lub możliwa do zrozumienia jedynie z kontekstu i np. tonu wypowiedzi. Pozornie wyglądające jak życzenia mogą być np. groźbą albo rozkazem² ${ }^{26}$

(49) Żebyś zawsze wiedział, gdzie jest twoje miejsce!

(50) Niech takie sytuacje nie mają więcej miejsca!

Albo na odwrót - życzeniami mogą być komunikaty, które w żaden sposób ich nie przypominają w warstwie językowej, np. zapewnienia i rozkazy.

(51) Wierzę, że im dokopiesz!

(52) Dokop im!

26 Zastosowane w nich partykuły bowiem nie są wyspecjalizowane w wyrażaniu życzeń. 
Do ich prawidłowego odbioru potrzebne są odpowiednie okoliczności i spełnione warunki fortunności, np. życzliwy ton, bliska relacja rozmówców czy gest, np. wskazujący na doping nadawcy.

Życzenia, jako działanie mowne zaliczane do grupy zwrotów grzecznościowych $^{27}$, odczytujemy za pomocą wykładników językowych. Zdarza się i tak, że do prawidłowej interpretacji wymagany jest kontekst. Życzenia przenikają się wzajemnie $\mathrm{z}$ innymi aktami mowy. Ich zakres jest bardzo szeroki - mogą być motywowane świętami lub okazjami albo próbą wyrażenia emocji samego nadawcy (Nikomu nie życzyłbym przė̇yć tego samego). Co więcej, życzenia często konwencjonalizują się w naszej kulturze i stają się gotowymi formułami językowymi, których używamy w konkretnej sytuacji społecznej - są wówczas wypowiadane ze względu na obowiązujące zasady zachowania w społeczeństwie albo ich nadawca nie dba o to, aby były spersonalizowane, i nie przykłada wagi do procesu ich komunikowania.

\section{Bibliografia}

Austin, J.L. (1993). Mówienie i poznawanie. Rozprawy i wykłady filozoficzne. Tłum. B. Chwedeńczuk. Warszawa: Wydawnictwo Naukowe PWN.

Bralczyk, J. (red.). (2005). Słownik 100 tysięcy potrzebnych słów. Warszawa: Wydawnictwo Naukowe PWN.

Dróżdż-Łuszczyk, K. (2017). Semantyka i składnia czasowników życzyć, gratulować, winszować, Prace Filologiczne, 70, 159-169.

Greń, Z. (1994). Semantyka i składnia czasowników oznaczających akty mowy w języku polskim i czeskim. Warszawa: Slawistyczny Ośrodek Wydawniczy.

Grodziński, E. (1980). Wypowiedzi performatywne. Wrocław: Zakład Narodowy im. Ossolińskich - Wydawnictwo PAN.

ISJP - Inny słownik języka polskiego. M. Bańko (red.). (2000). Warszawa: Wydawnictwo Naukowe PWN.

Jędrzejko, E., Kita, M. (2002). Z najlepszymi życzeniami, czyli o dobrych życzeniach i języku życzliwym. Warszawa: „Ex Libris”. Galeria Polskiej Książki.

Krasiński, S. (1885). Słownik synonimów polskich. Kraków: Akademia Umiejętności.

Marcjanik, M. (2008). Grzeczność w komunikacji językowej. Warszawa: Wydawnictwo Naukowe PWN.

Markowski, A. (red.). (2004). Wielki słownik poprawnej polszczyzny PWN. Warszawa: Wydawnictwo Naukowe PWN.

27 O życzeniach w tej perspektywie można przeczytać również w literaturze popularnonaukowej, np. „Z najlepszymi życzeniami, czyli o dobrych życzeniach i języku życzliwym” (Jędrzejko, Kita 2002). 
Mędak, S. (2005). Praktyczny słownik łączliwości składniowej czasowników polskich. Kraków: TAiWPN UNIVERSITAS.

Ożóg, K. (1990). Zwroty grzecznościowe wspótczesnej polszczyzny mówionej. Warszawa-Kraków: Wydawnictwo Naukowe PWN.

SEJPBor - W. Boryś (2005). Słownik etymologiczny języka polskiego. Kraków: Wydawnictwo Literackie.

SEJPBr - Brückner, A. (1927). Słownik etymologiczny języka polskiego. Krakowska Spółka Wydawnicza; reprint 2000, Warszawa: Wiedza Powszechna.

Sikora, K. (2013). Życzenia i winszowanie jako akt mowy, LingVaria 16, 179-189.

SJPDor - W. Doroszewski (red.). (1958-1969). Słownik języka polskiego. Warszawa: Państwowe Wydawnictwo Naukowe.

SW - Karłowicz, J., Kryński, A.A., Niedźwiedzki, W. (red.). (1900-1927). Słownik języka polskiego. Warszawa.

Wierzbicka, A. (1973). Akty mowy. W: M.R. Mayenowa (red.), Semiotyka i struktura tekstu. Studia poświęcone VII międzynarodowemu kongresowi slawistów (201-219). Warszawa: Zakład Narodowy im. Ossolińskich - Wydawnictwo Polskiej Akademii Nauk.

Żmigrodzki, P. (2007). Wielki słownik języka polskiego. Kraków: Instytut Języka Polskiego PAN. Pozyskano z http://www.wsjp.pl/index.php?pokaz=wstep\&l=1\&ind=0?pwh=0

\section{Streszczenie}

Przedmiotem artykułu jest charakterystyka czasownika $\dot{z} y c z y c ́$ oraz opis czynności składania życzeń. Badania opierają się na analizie semantycznej i składniowej, uwzględniają również kontekst wypowiedzi. Autor rozważa intencjonalność składania życzeń i analizuje pozycje składniowe otwierane przez czasownik życzyć. Życzenia są działaniem mownym, mogą być rozpatrywane jako zachowanie grzecznościowe. 